\title{
TRANSFORMATION OF RURAL RESETTLEMENT ON REGIONAL LEVEL (THE EXAMPLE OF CHERNIHIV REGION)
}

\author{
Mykola BARANOVSKY \\ Nizhyn Gogol State University, Ukraine \\ Brnm@ukr.net
}

\begin{abstract}
The economic and socio-political factors caused transformational changes in rural settlement system of Chernihiv region. The reasonability of their analysis is caused by practice demands, and changes evaluation is based on data concerning population size of almost 1500 rural localities of Chernihiv region in 1989, 2001 and 2014. The study reveals that during 1989-2014 rural settlement network of the region reduced by 100 localities, and the localities with the population size of less than 50 people have the fastest level of inhabitants decrease - above $77 \%$. With the increase of localities population size depopulation rate slows down. Thus, the analysis of empirical data (grouping of rural localities in accordance with population size) proves that distinctive peculiarities of structure of Chernihiv region rural settlement system are the following: settling in small localities and general increase in irregularity of population distribution. The evidence of small localities settlement is the rise of the part of very small rural localities in settlement network structure. During 1989 - 2014 the share of villages with the population size up to 50 people grew from 15.8\% to 33\%. The irregularity in population distribution is observed through the share increase of rural inhabitants that dwell in the localities of different population size. While in 1989 the main part of rural inhabitants lived in the villages with the population size up to 500-1000 and 10002000 people (62.7\%), currently - in the villages with population up to 200-500 and 500-1000 people (67.4\%). Eventually, the author proves the reasonability of using analysis results for administrative-territorial reform implementation, optimization of educational and medical establishment network in Chernihiv region.
\end{abstract}

Key words: settlement system, rural settlement, localities, population size of villages, transformation of settlement, settlement network.

UDC: $911.373(477.51)$

\section{ТРАНСФОРМАЦІЯ СІЛЬСЬКОГО РОЗСЕЛЕННЯ НА РЕГІОНАЛЬНОМУ РІВНІ (НА ПРИКЛАДІ ЧЕРНІГІВСЬКОЇ ОБЛАСТІ)}

\author{
Микола БАРАНОВСЬКИЙ \\ Ніжинський державний університет імені Миколи Гоголя, Україна \\ Brnm@ukr.net
}

\begin{abstract}
Анотація: Обґрунтовано доцільність наукового аналізу трансформації системи сільського розселення Чернігівської області у пострадянський період. Проведено аналіз динаміки кількісного складу поселенської мережі та людності сільських населених пунктів регіону за 1989, 2001 та 2014 рр. Встановлено міжрайонні відмінності у динаміці сільських поселень і середньої людності сіл упродовж 1989-2014рр. Проведено групування сільських поселень Чернігівської області за кількістю жителів, визначено структуру її поселенської мережі. Охарактеризовано особливості концентрації населення у сільських поселеннях різної людності, виявлено тенденції перерозподілу сільського населення між різними групами населених пунктів. Доведено доцільність використання результатів дослідження при проведенні адміністративно-територіальної реформи у Чернігівській області.
\end{abstract}

Ключові слова: система розселення, сільське розселення, населені пункти, людність сіл, трансформація розселення, поселенська мережа.

Удк: $911.373(477.51)$

Вступ. Постановка проблеми. Зміна ще на початку 90-х років XX ст. економічної моделі розвитку України зумовила цілу низку перетворень i зрушень, які охопили усі сфери ii життя - реальний сектор економіки, систему розселення, інфраструктуру тощо. Попри значний перехідний період, який триває вже майже 25 років, трансформаційні зміни у багатьох сферах країни ще не завершилися. При цьому важливо знати головні тренди і напрями таких перетворень, які можна визначити лише на основі порівняльного аналізу розвитку тих чи інших явищ за значний часовий інтервал.

(C) М. Барановський
Система розселення презентує поселенську основу будь-якого регіону, вона надзвичайно тісно пов'язана 3 його економікою, соціальною інфраструктурою, транспортною мережею тощо. В усі часи вивченню систем розселення у суспільній географії приділялася велика увага. У сучасних умовах особливо прискіпливої оцінки потребують питання, пов'язані 3 аналізом змін, які сталися у низових системах розселення у пострадянський період розвитку України. Полігоном дослідження у даному випадку було обрано Чернігівську область, яка на тлі інших регіонів України вирізняється складним перебігом демографічних і соціальних процесів.

Аналіз останніх досліджень і публікацій. На загальнодержавному рівні грунтовний аналіз 
розвитку сільського розселення здійснив А. Доценко [2]. Сучасні проблеми розселення у контексті реформування адміністративнотериторіального устрою викладені у монографічному дослідженні Л. Заставецької [5]. Вивченням системи розселення Чернігівської області у різні роки займалися В. Завгородній, В. Смаль, О. Афоніна. Деякі аспекти зазначеної проблематики, зокрема вплив демографічних і розселенських процесів на формування депресивності окремих територій, розкриті у роботах М. Барановського [1] та у колективній монографії [3]. Водночас розселенські та, особливо, демографічні процеси є вкрай динамічними. Від моменту проведення останнього перепису населення в Україні пройшло майже 15 років. В умовах гострої економічної кризи, трансформаційних зрушень у реальному секторі економіки, насамперед в аграрній сфері, у системах розселення різного рангу також сталися помітні структурні зміни та зрушення. Вони потребують наукового аналізу та узагальнення, особливо на етапі проведення адміністративно-територіальної реформи.

Поставка завдання. Формулювання цілей статті. Головним завданням даного дослідження $\epsilon$ аналіз трансформаційних змін, які сталися у сільському розселенні Чернігівської області у пострадянський період їі розвитку.

Виклад основного матеріалу. Першоосновою наукового аналізу змін у системі розселення $\epsilon$ формування відповідної статистичної бази та вибір адекватних специфіці проблематики методів дослідження.

Для оцінки змін, які сталися у системі сільського розселення Чернігівської області, було проаналізовано динаміку кількості та людності усіх сільських поселень регіону за 1989-2014 рр. Інформаційну базу дослідження склали дані результатів переписів населення 1989 та 2001 рр., а також статистичні викладки, які містяться у паспортах новостворених територіальних громад. Наведені там цифрові дані щодо кількості населення у розрізі сільських поселень датуються початком 2015 p. i наразі $\epsilon$ найбільш сучасними, оскільки останній перепис населення в Україні проводився у грудні 2001 р. Для аналізу трансформаційних змін у системі сільського розселення Чернігівської області використовувалися традиційні методи, зокрема статистичний, групування, порівняльно-географічний.

Системи розселення будь-якого рангу характеризуються, 3 одного боку, постійними змінами як у часі, так i у просторі, 3 іншого інерційністю розвитку, формами прояву якої є збереження кількісного складу поселень та їх територіальних меж. Дослідники пропонують розглядати трансформацію сільського розселення у трьох аспектах - поселенському, формаційному та структурному [2, с. 90].

Перший аспект включає оцінку динаміки кількості сільських населених пунктів Чернігівської області. Загалом у регіоні налічується досить значна кількість сільських поселень, що є закономірним явищем, зважаючи на значні розміри території
Чернігівщини, ii давню заселеність, сприятливість природних чинників для проживання та господарської діяльності людей. Станом на початок 2015 р. у регіоні нараховувалося 1422 сільські поселення, у яких є постійні мешканці. Крім цього, в області налічується понад 40 сільських поселень без жителів. Вони ще перебувають на обліку, чим власне i пояснюється невідповідність між офіційними даними управління статистики щодо кількості поселень i даними, отриманими за результати аналізу паспортів новостворених громад. Найбільшу кількість сільських поселень мають Козелецький (107), Ріпкинський (112) та Чернігівський (120) райони. Загалом в області чітко простежується пряма залежність між розмірами території району i кількістю поселень у них.

На жаль, Чернігівщина належить до тих регіонів України, які характеризуються швидкими темпами деградації сільської поселенської мережі. Загалом за 1989-2014 рр. кількість сільських поселень у Чернігівській області скоротилася майже на 100 одиниць (6,4\%). Тільки у 2013 р. обласна рада зняла 3 обліку відразу 15 сільських поселень. Найбільш інтенсивно скорочення поселенської мережі проходило у Семенівському (21,7\%), НовгородСіверському (16,3\%), Борзнянському (12,7\%) та Варвинському (10,3\%) районах. Аналогічні процеси простежувались у Чернігівській області і у більш віддалені часи, про що зазначається у дослідженні В. Смаль [4, с. 36]. Головною причиною таких негативних тенденцій є несприятлива демографічна ситуація та міграційний відтік, насамперед, молоді із сільської місцевості. Інші причини є менш вагомими. Серед них варто відзначити зміни у статусі населених пунктів. Йдеться про перехід окремих сільських поселень до категорії селищ міського типу та навпаки. Упродовж 1989-2014 рр. селищем міського типу стало село Гончарівське (Чернігівський район). Більш активними були протилежні процеси. Відповідно до звернення місцевих громад, мотиваційними чинниками яких були зміна структури зайнятості населення та різниця в оплаті комунальних послуг, Верховна Рада України своїм рішенням позбавила статусу селища міського типу поселення Вертіївка (Ніжинський район) та Новий Биків (Бобровицький район). Аналізуючи постійний процес скорочення поселенської мережі, варто звернути увагу на певні особливості у його протіканні: 1) скорочення поселенської мережі помітно пришвидшилося на початку 2000-х років через ускладнення економічної ситуації та організаційні перетворення в аграрному секторі; 2) більш швидкими темпами скорочення кількості поселень проходило у північних районах області, які вирізняються складною демографічною ситуацією, гіршим розвитком транспортної мережі та низькою доступністю для сільських мешканців закладів соціальної інфраструктури. Зважаючи на динаміку людності сільських поселень, у перспективі слід очікувати подальшого скорочення їх кількості. Станом на початок 2015 р. в області налічувалося 105 сільських поселень людністю до 5 осіб, у тому числі 30 сіл, де мешкає лише один житель. 
Аналізу динаміки різних за формою типів населених пунктів не приділяється належна увага у наукових дослідженнях, оскільки зазначені аспекти мало впливають на характер сільського розселення. У межах Чернігівської області в останні роки головними формами територіальної організації сільського розселення є села, селища та хутори. При цьому частка перших у загальній кількості сільських поселень є домінуючою - понад 95\%. Перші селища з'явилися на території Чернігівської області у сучасних її межах у кінці XIX ст. У 70-80-х роках $\mathrm{XX}$ ст. у селищах розміщувалися або центральні садиби і відділення радгоспів, або вони виконували промислові, транспортні, лісогосподарські та рекреаційні функції. Зазвичай селища мають незначну людність і тому з 1989 до 2014 рр. їх кількість скоротилася в регіоні з 63 до 37 одиниць. Найбільше селищ налічується у Бахмацькому та Семенівському районах. Варто зауважити, що таке інтенсивне скорочення кількості селищ пов'язане не лише із зменшенням населення у них, а й 3 наданням ім статусу села.

Хутори, як форма сільських населених пунктів були досить поширені у кінці XIX - на початку XX ст. Наразі їх практично не залишилося. За даними паспортів новостворених сільських громад, офіційно як хутір записано лише одне поселення у Козелецькому районі.

Найбільш працеємним і суспільно значущим етапом дослідження трансформаційних змін у сільському розселенні регіону $є$ аналіз його структури. 3-поміж показників структурної трансформації сільського розселення найважливішим є людність сільських поселень. При цьому йдеться як про пересічні для адміністративних районів показники людності сільських поселень, так і їх групування за кількістю мешканців.

Вище було проаналізовано динаміку кількості сільських населених пунктів Чернігівської області. Загалом сільська поселенська мережа регіону скоротилася на $6,4 \%$. Значно швидшими темпами скорочується в області кількість сільського населення. За 1989-2014 pp. воно зменшилося на 46,4\%. Відповідно пересічна для області людність сільських населених пунктів скоротилася за вказаний період на 42,7\% - 3 458,7 до 263 осіб. Найбільш інтенсивне скорочення людності сільських поселень мало місце у Ріпкинському $(49,4 \%)$, Козелецькому $(49,1)$ та Носівському $(47,1 \%)$ районах. Щодо тих районів, де зменшення людності сільських поселень виявилося найнижчим (Варвинський, НовгородСіверський, Ніжинський), то це пояснюється, 3 одного боку, відносно невисокими темпами убутку сільського населення, 3 іншого - пропорційним скороченням кількості сільського населення та чисельності самих сіл.

3 точки зору оцінки перспектив існування поселенської мережі доцільно проаналізувати особливості скорочення населення у різних за людністю сільських поселеннях. Для вирішення цього завдання було визначено темпи скорочення людності усіх сільських населених пунктів Чернігівської області за 1989-2014рр. Як і очікувалося, найвищими темпами убутку населення вирізняються малі за людністю сільські поселення. Так, у селах людністю до 50 осіб населення скоротилося за вказаний період на 77,6\%. У середніх і великих сільських поселеннях темпи убутку населення помітно нижчі (рис. 1). Особливо це стосується поселень людністю 1000-2000 та 2000-3000 жителів, де темпи убутку населення $є$ мінімальними - 27,7 та 24,9\% відповідно.

Окремо варто зупинитися на аналізі абсолютних показників людності сільських поселень. Чернігівщина посідає передостаннє місце у рейтингу регіонів України за цим показником. На початок 2015 р. пересічна людність сільських населених пунктів у регіоні становила 263 особи. Досить значними залишаються міжрайонні диспропорції у людності сільських поселень. Максимальне значення (494,7 осіб, Куликівський район) перевищує мінімальне (123,1 осіб, Ріпкинський район) у 4 рази.

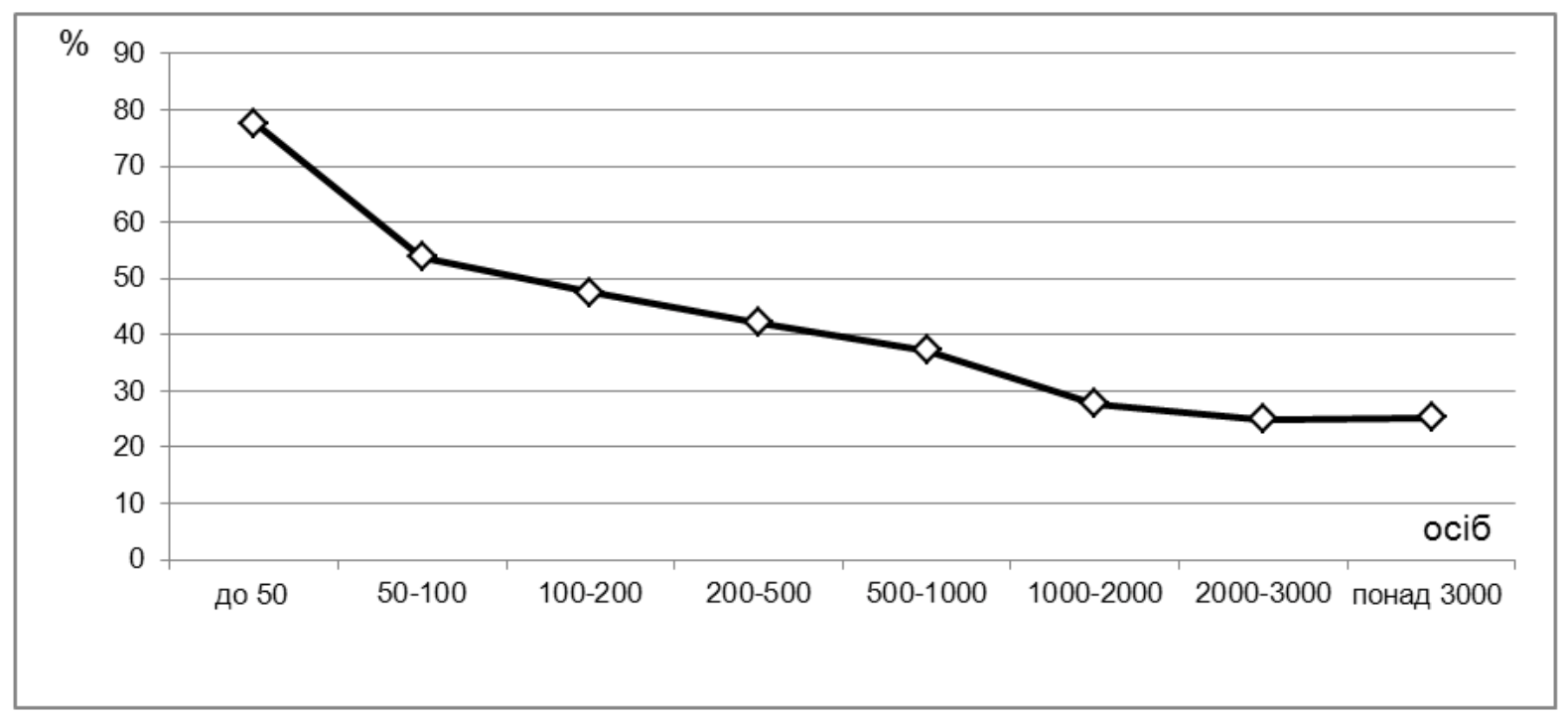

Рис. 1. Темпи скорочення населення у сільських поселеннях різної людності, \% 
Традиційно низькими показниками людності сільських поселень вирізняються північні райони області (Городнянський, Корюківський, НовгородСеверський, Семенівський), які розміщуються на Поліссі. Низька людність сільських поселень породжує цілу низку проблем, пов'язаних із можливістю надання населенню різноманітних послуг. У селах людністю 50-100 осіб відсутні будьякі заклади соціальної інфраструктури (дитячі садки, школи, медичні заклади і навіть магазини), досить часто до них не ходить громадський транспорт. Така ситуація ще більше пришвидшує деградацію сільської поселенської мережі, a, відповідно, і сільських територій загалом.

В області практично відсутні сільські поселення, де б спостерігалася стала позитивна динаміка зростання кількості населення, за винятком села Чайкине Новгород-Сіверського району. В окремих випадках мало місце збільшення людності сіл у період між 1989 та 2001 рр., проте це зростання нівелювалося зменшенням населення упродовж 2001-2014 pp. Аналіз сільських поселень, які вирізняються найнижчими темпами убутку населення, дозволяє стверджувати, що, по-перше, вони здебільшого займають зручне географічне положення (знаходяться на транспортних комунікаціях, поблизу міст Чернігова та Ніжина), подруге, їх населення зайняте несільськогосподарською діяльністю (с. Ягідне, селище Газопровідне), по-третє, у більшості випадків ці поселення мають незначну кількість жителів.

Поряд із загальним аналізом, важливе значення має групування сільських поселень за показниками людності. Традиційний поділ сільських населених пунктів на малі, середні та великі дає лише загальне уявлення про стан сільського розселення. Для поглибленого аналізу необхідно розподілити сільські поселення на щонайменше вісім груп: 1) до 50 осіб; 2) $50-100$; 3) $100-200$; 4) 200-500; 5) $500-1000$; 6) 1000-2000; 7) 2000-3000; 8) понад 3000 осіб. Такий поділ досить часто зустрічається у суспільно-географічних дослідженнях, особливо на регіональному рівні.

Аналіз групування сільських поселень Чернігівської області за людністю, який базується на

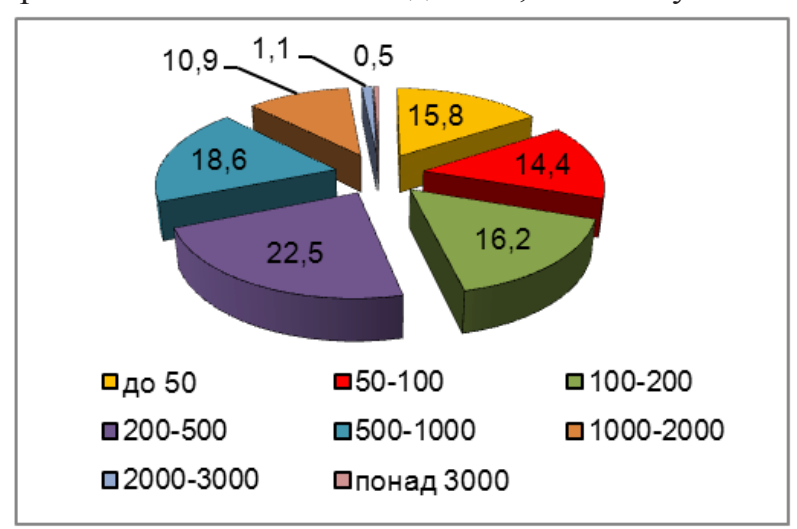

Рис. 2. Частка сільських поселень різної людності у загальній поселенській мережі Чернігівської області, \% (1989 p.) даних 1989 та 2014 рр., дозволяє визначити траєкторію переходу населених пунктів із однієї групи до іншої. Загальний вектор змін полягає у зростанні питомої ваги сільських поселень найменшої людності. Якщо у 1989 р. частка населених пунктів із числом жителів до 50 осіб становила у Чернігівській області $15,8 \%$, то у 2014 р. - уже 33\%. Натомість майже у 4 рази скоротилася питома вага сільських поселень людністю 1000-2000 жителів (рис. 2, 3). Головною причиною такого явища $є$ знелюднення сільських населених пунктів через ускладнення демографічної ситуації та міграційний відтік молоді з сільської місцевості.

Міжрайонні відмінності у розподілі сільських поселень за людністю залишаються досить значними. Наразі найвищою часткою дуже малих за людністю сільських поселень вирізняються північні райони області - Семенівський, Ріпкинський, Корюківський та Городнянський. У 1989 р. ситуація була дещо іншою. Крім північних, Семенівського та НовгородСіверського районів, значною часткою малих сіл вирізнялися тоді Срібнянський, Бахмацький та Ічнянський райони.

Щодо великих за людністю сільських поселень, то їх кількість в області неухильно зменшується. За результатами перепису населення 1989 р., у регіоні налічувалося 191 село, людність яких перевищувала 1000 осіб (12,5\%). Тепер таких сіл залишилося лише 46 (3,7\%). Перелік районів, у яких частка великих за людністю сіл є відносно значною, залишається сталим - це Куликівський, Менський, Бобровицький та Чернігівський адміністративні райони.

Як показали результати аналізу, у Чернігівській області найбільш поширеними є сільські поселення, людністю 200-500 та 500-1000 осіб. Причому це характерно для різних часових періодів. У 1989 р. питома вага сільських поселень людністю 200-500 осіб становила в області $22,5 \%$, у 2014 р. - 24\%. Аналогічна ситуація із сільськими поселеннями, що налічують 500-1000 мешканців - 18,6 та 14,7\% відповідно. Сумарно поселення людністю 2001000 осіб становлять близько 40\% від загальної поселенської мережі Чернігівської області. Таку ситуацію можна пояснити значними інтервалами цих груп та поступовою «міграцією» сільських поселень

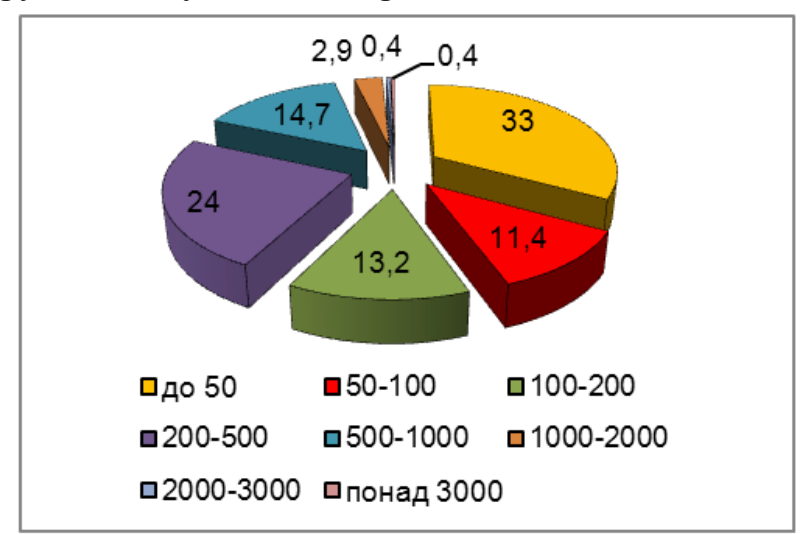

Рис. 3. Частка сільських поселень різної людності у загальній поселенській мережі Чернігівської області, \% (2014 p.) 
iз груп більшої до груп меншої людності. Водночас в області зустрічаються райони, де зазначені співвідношення мають відхилення у той чи інший бік. Наприклад у Куликівському, Борзнянському, Срібнянському та Чернігівському районах частка сіл людністю 200-1000 осіб перевищує 50\%, тоді як у Бахмацькому, Корюківському, Ріпкинському та Семенівському - вона складає близько 20-23\%.

Традиційною для сільського розселення будьякого регіону є невідповідність між часткою сільських поселень певної людності і часткою населення, що проживає у них. Не є винятком у цьому відношенні i Чернігівська область. Зазвичай, найбільша невідповідність простежується для малих і великих за людністю сільських поселень. У $33 \%$ сільських поселень Чернігівської області людністю до 50 осіб проживає лише 2,5\% населення (табл. 1). Сумарно у селах людністю до 200 осіб, які складають майже $60 \%$ поселенської мережі регіону, сконцентровано лише 14,4\% сільського населення. Протилежна ситуація сформувалася для великих сіл. У поселеннях людністю понад 1000 осіб, які складають лише 3,7\% загальної кількості сільських населених пунктів області, проживає 18,2\% її населення.

Результати аналізу свідчать про те, що тепер у Чернігівській області основна частина сільського населення сконцентрована у населених пунктах, людністю 200-500 та 500-1000 осіб. Сумарно у них мешкає понад 67\% сільського населення регіону. Ці села наразі $є$ головним структурним ядром поселенської мережі Чернігівської області. За результатами перепису 1989 р., ситуація була дещо іншою. Тоді найбільший людський потенціал був зосереджений у сільських поселеннях людністю 500-1000 та 1000-2000 осіб - понад 62\% (табл. 1). Отже, з часом концентрація сільського населення посилюється.

Додатковим підтвердженням цього є величина показника рівня концентрації сільського населення за 1989 та 2014 рр., який визначався за формулою:

$$
h=\frac{\sum_{i=1}^{n}\left|X_{i}-Y_{i}\right|}{2},
$$

де $X_{i}$ - частка і-го району v загальній кількості сільського населення області, $Y_{i}$ - частка і-го району у площі області. У 1989 р. величина цього показника становила 8,1 од., у 2014 р. - 11,4 од.

Виявлені особливості розподілу сільських поселень і населення за групами різної людності мають важливе прикладне значення у контексті оптимізації системи освітніх і медичних закладів у сільській місцевості, при проведенні адміністративно-територіальної реформи. Найбільш гострою залишається проблема надання різноманітних послуг жителям малих за людністю сільських поселень (до 100 осіб), попри те, що у них мешкає близько $6 \%$ населення. Існування у таких населених пунктах стаціонарних закладів сфери послуг, навіть магазинів, є нерентабельним, проте держава зобов'язана забезпечити доступ населення цих сільських поселень до базових життєвих стандартів.

Дрібноселенність розселення, наявність сільських рад, у яких мешкає менше 150 осіб, є тими вагомими аргументами, спираючись на які державні органи обгрунтовували доцільність проведення в Україні адміністративно-територіальної реформи. Дійсно, сільські громади 3 незначною кількістю жителів, відсутністю об’єктів соціальної інфраструктури, слабкою економічною базою не можуть бути хоча 6 відносно фінансово самодостатніми. Встановлені особливості галузевої структури системи сільського розселення мають стати науковим підгрунтям проведення адміністративно-територіальної реформи у Чернігівській області.

Висновки та перспективи подальших досліджень. Проведений аналіз трансформаційних змін у сільському розселенні Чернігівської області дає підстави сформулювати такі висновки.

1. У пострадянський період розвитку регіону чітко простежується тенденція до скорочення кількості сільського населення, мережі сільських поселень та їх людності. За 1989-2014 рр. сільська поселенська мережа Чернігівської області скоротилася більш як на 100 населених пунктів, а їх пересічна людність майже удвічі - 3 458,7 до 263 осіб. Найбільш швидкі темпи убутку населення мають сільські поселення людністю до 50 осіб - 77,6\%. Найповільніше втрачають жителів сільські поселення, у яких мешкає від 2000 до 3000 осіб - 24,9\%. Дуже низькою людністю сільських поселень вирізняються

Таблиияя 1

Концентрація населення у сільських поселеннях різної людності, \%

\begin{tabular}{|l|c|c|c|}
\hline \multirow{2}{*}{$\begin{array}{c}\text { Групи сільських } \\
\text { поселень }\end{array}$} & \multicolumn{3}{|c|}{ Роки } \\
\cline { 2 - 4 } & 1989 & 2001 & 2014 \\
\hline до 50 осіб & 1,1 & 1,8 & 2,5 \\
\hline $50-100$ & 2,7 & 2,7 & 8,4 \\
\hline $100-200$ & 5,6 & 6,3 & 31,5 \\
\hline $200-500$ & 17,8 & 21,5 & 35,9 \\
\hline $500-1000$ & 31,2 & 36,9 & 11,6 \\
\hline $1000-2000$ & 31,5 & 21,5 & 2,9 \\
\hline $2000-3000$ & 5,7 & 3,6 & 3,7 \\
\hline понад 3000 & 4,3 & 5,5 & \\
\hline
\end{tabular}

Розраховано автором за результати переписів населення 1989 і 2001 рр. і даними паспортів новостворених територіальних громад 
північні райони області - Ріпкинський, Семенівський, Корюківський та Новгород-Сіверський.

2. У структурі поселенської мережі Чернігівської області домінують дуже малі та малі за людністю сільські поселення. Наразі частка сіл, людністю до 100 осіб, становить у регіоні понад 44\%. Упродовж 1989-2014 рр. мало місце постійне подрібнення сільської поселенської мережі області, свідченням чого є невпинне зростання частки дуже малих сіл i скорочення питомої ваги середніх та великих за людністю сільських населених пунктів.

3. В останні десятиліття у Чернігівській області посилюється концентрація сільського населення. Понад 67\% сільських жителів проживають у поселеннях людністю 200-500 та 500-1000 осіб. Натомість у селах людністю до 50 осіб, які складають $33 \%$ поселенської мережі регіону, мешкає лише 2,5\% сільського населення. Міжрайонні особливості концентрації сільського населення визначаються неоднаковими темпами скорочення населення у сільських поселеннях різної людності.

4. Головними причинами негативних трансформаційних змін у системі сільського розселення Чернігівської області $є$ ускладнення економічної ситуації у 90-х роках ХХ ст., погіршення демографічних показників, міграційний відтік молоді із села, організаційно-інституційні перетворення в аграрному секторі. Визначені особливості динаміки та структури системи сільського розселення Чернігівської області мають важливе прикладне значення у контексті проведення адміністративно-територіальної реформи.

Системи розселення, як і елементи територіальної структури господарства, трансформуються під впливом змін у перебігу економічних і демографічних процесів. Поряд із зрушеннями, які сталися у морфологічній структурі сільського розселення Чернігівської області, вкрай актуальним залишається завдання аналізу сучасної територіальної структури системи розселення регіону. Визначені центри і системи розселення різного рангу мають стати науковим підгрунтям при формуванні центрів територіальних громад, при реформуванні системи загальноосвітніх навчальних закладів i медичних установ у регіоні.

\section{References:}

1. Baranovs'kij M. O. Naukovìzasadi suspil'no-geografičnogo vivčennâ sil's'kih depresivnih terytorìj Ukraïni [The scientific basis of socio-geographic study of rural depressed areas of Ukraine]. Nizhyn, 2009, 396 p. (In Ukrainian).

2. Docenko A.İ. Sil's'ke rozselennâ v Ukrä̈ni: dinamika ta struktura [Rural settlement in Ukraine: dynamics and structure]. Kyiv, 2010, 288 p. (In Ukrainian).

3. Sil's'ki depresivnì teritorï Polìssâ: osoblivostì rozvitku ta sanacï [Polissya rural depressed areas: features of development and recovery]. Nizhyn, 2010, 315 p. (In Ukrainian).

4. Smal' V. V. Osobennosti morfologičeskoj strukrury Černigovskoj oblastnoj sistemy rasseleniâ. [Peculiarities of morphological structure of the Chernihiv regional settlement system]. Ekonomičeskaâ geografiâ. [Economic geography], 1990, Vol. 42, pp. 33-38. (In Russian).

5. Zastavec'ka L. B. Sistemi rozselennâ ì geoprostorovì problemi vdoskonalennâ adminìstrativno-teritorìal'nogo usroû v Ukraïni [Resettlement systems and geospatial problems of improving of the administrative-territorial structure of Ukraine]. Ternopil, 2013, 332 p. (In Ukrainian). 